\title{
3-O-Demethylswertipunicoside Protects against Oxidative Toxicity in PC12 Cells
}

\author{
Shi-Ping Zhang, ${ }^{a, b}$ Xin-Gang Du, ${ }^{c}$ and Xiao-Ping PU ${ }^{*, a, b}$ \\ ${ }^{a}$ State Key Laboratory of Natural and Biomimetic Drugs, Peking University; ${ }^{b}$ Department of Molecular and Cellular \\ Pharmacology, Peking University; and ${ }^{c}$ Department of Natural Drugs, School of Pharmaceutical Science, Peking \\ University; Beijing 100191, P. R. China. Received April 2, 2010; accepted May 20, 2010; published online June 15, 2010
}

\begin{abstract}
Xanthone compounds have been reported to inhibit cancer cell growth as well as possessing antioxidant properties. The xanthone compound 3-O-demethylswertipunicoside (3-ODS), extracted from Swertia punicea Hemsl, has not previously been demonstrated to have clear neuroprotective effects. In our study, the 3-(4,5-dimethylthiazol-2-yl)-2,5-diphenyltetrazolium bromide (MTT) cell death assay revealed that treatment of PC12 cells with 3-ODS ameliorated the decreased cell viability induced by exposure to 1-methyl-4-phenylpyridinium ion $\left(\mathrm{MPP}^{+}\right)$, rotenone or $\mathrm{H}_{2} \mathrm{O}_{2}$. The acridine orange/ethidium bromide (AO/EB) apoptosis assay demonstrated a significant suppression of cell death in PC12 cells. by 3-ODS treatment. 3-ODS increased the protein expression of both tyrosine hydroxylase (TH) and DJ-1 expression in PC12 cells. The current study demonstrates that 3ODS has potential neuroprotective effects mediated via the elevation of TH and DJ-1 protein levels.
\end{abstract}

Key words 3-O-demethylswertipunicoside; neuroprotection; PC12 cell; 1-methyl-4-phenylpyridinium ion; tyrosine hydroxylase; DJ-1

Neurodegenerative diseases constitute a significant source of morbidity and suffering in all human populations. Parkinson's disease (PD) is a devastating neurodegenerative disorder, affecting $1-2 \%$ of the population over the age of 50 years, ${ }^{1)}$ affecting over 6 million people worldwide. Recent epidemiological projections show the incidence of PD to be continuously increasing as populations age, and it is anticipated that the number of affected individuals may double within the next 20 years in the most populous nations. ${ }^{2}$ A number of toxins can induce Parkinsonian symptoms. The dopaminergic neurotoxin, 1-methyl-4-phenylpyridinium $\left(\mathrm{MPP}^{+}\right)$, a metabolite of 1-methyl-4-phenyl-1,2,3,6-tetrahydropyridine (MPTP), has been widely used as an inducer of animal models of PD., ${ }^{3,4)}$ Rotenone is a widely-used pesticide. Administration of rotenone can induce biochemical and histological changes similar to those of PD in rats. ${ }^{5)}$ Endogenous factors may also lead to the symptoms of PD. There is evidence that oxidative stress is a causative, or at least an ancillary factor in the pathogenesis of major neurodegenerative diseases such as PD. ${ }^{6)}$ Oxidative stress caused by mitochondrial dysfunction and the oxidative metabolism of dopamine also play an important role in the pathogenesis of PD. ${ }^{7,8} \mathrm{Hy}-$ drogen peroxide $\left(\mathrm{H}_{2} \mathrm{O}_{2}\right)$ easily damages biological molecules, resulting in apoptotic or necrotic cell death. $\mathrm{H}_{2} \mathrm{O}_{2}$ has been extensively used as an inducer of oxidative stress in in vitro models. ${ }^{9)}$ The rat pheochromocytoma cell line PC12 has been utilized as a neuron-like cell suitable as a dopaminergic nerve cell model for PD research. ${ }^{10)}$

Xanthones have been shown to possess antioxidative effects. ${ }^{11)}$ These compounds can also inhibit the growth of human cancer cells, and possess promising therapeutic potential. $^{12)}$ The xanthone 3-O-demethylswertipunicoside (3ODS) (Fig. 1) is a type characterized as containing a number of phenol-hydroxyl groups. 3-ODS is extracted from Swertia punicea HemsL (Gentianaceae) $)^{13,14)}$ and is mainly distributed in southwest China. As an important traditional Chinese medicine, this plant derivative is used for the treatment of hepatitis and cholecystitis. ${ }^{15)}$ It has not been shown whether or not 3-ODS has protective effects against $\mathrm{MPP}^{+}$-induced

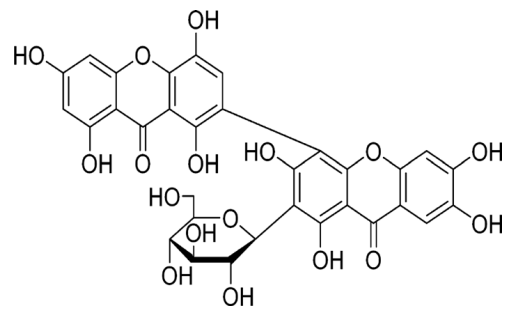

Fig. 1. The Chemical Structure of 3-ODS

neurotoxicity. The aim of the present study was to investigate the mechanisms underlying the potential neuroprotective effects of 3-ODS.

\section{MATERIALS AND METHODS}

Materials Swertia punicea HemsL was collected in Sichuan Province, P. R. China. 3-ODS was extracted by Dr. Du Xin-Gang (Department of Natural Drugs, School of Pharmaceutical Science, Peking University). 3-ODS purity was more than $98 \%$ by high-performance liquid chromatography (HPLC) analysis. ${ }^{16)}$ Poly-L-lysine, $\mathrm{MPP}^{+}$, 3-(4,5-dimethylthiazol-2-yl)-2,5-diphenyltetrazolium bromide (MTT), $N, N$-dimethyl sulfoxide (DMSO), rotenone and Hoechst 33342 were purchased from Sigma (U.S.A.). Acridine Orange (AO) was purchased from M\&C Gene Technology Company (China). Ethidium bromide (EB) was obtained from Amresco (U.S.A.). F12K cell culture medium was purchased from Invitrogen (Carlsbad, CA, U.S.A.). The antityrosine hydroxylase $(\mathrm{TH})$ rat monoclonal antibody was purchased from Santa Cruz Biotechnology (U.S.A.). Anti-DJ-1 rabbit polyclonal antibody was provided by Prof. Hiroyoshi Ariga (Graduate School of Pharmaceutical Sciences, Hokkaido University, Japan). All other reagents were of analytical grade.

Cell Culture and Treatments PC12 cells purchased from Shanghai Cell Culture Center, China were maintained in F12K with L-glutamine $(292 \mathrm{mg} / \mathrm{l})$ medium containing $5 \%$ fetal bovine serum, $15 \%$ equine serum, $100 \mathrm{U} / \mathrm{ml}$ penicillin, 
and $100 \mu \mathrm{g} / \mathrm{ml}$ streptomycin in a water-saturated atmosphere of $5 \% \mathrm{CO}_{2}$ at $37^{\circ} \mathrm{C}$. Cells were sub-cultured every $3 \mathrm{~d}$ and in culture for 2 weeks before being used for experiments.

Cell Viability Assay PC12 cells were incubated in 96well microplates $\left(2 \times 10^{4}\right.$ cell/well in $\left.100 \mu \mathrm{l}\right)$ for $24 \mathrm{~h}$. Cell viability was measured using the MTT assay. ${ }^{17,18)}$ Briefly, PC12 cells were pretreated with 3-ODS (dissolved in DMSO and then diluted in phosphate buffered saline (PBS)) for $6 \mathrm{~h}$, and then treated with $1 \mathrm{mM} \mathrm{MPP}^{+}$for $24 \mathrm{~h}, 0.5 \mu \mathrm{M}$ rotenone for $48 \mathrm{~h}$ or $250 \mu \mathrm{M} \mathrm{H} \mathrm{O}_{2}$ for $1 \mathrm{~h}$ at $37^{\circ} \mathrm{C}$, respectively. The controls were exposed to the same solvent. After treatment with $5 \mathrm{mg} / \mathrm{ml} \mathrm{MTT}$ for $4 \mathrm{~h}$ and $10 \%$ sodium dodecyl sulfate (SDS) overnight, the absorbance was read at $570 \mathrm{~nm}(630 \mathrm{~nm}$ as a reference) on a microplate reader. Cell viability was expressed as a percent of the control culture value.

AO/EB Staining Analysis PC12 cells were plated on coverslips pre-coated with poly-L-lysine in culture dishes. Cells were pre-treated with 3-ODS for $6 \mathrm{~h}$, and then treated with $1 \mathrm{~mm} \mathrm{MPP}^{+}$for $24 \mathrm{~h}$ at $37^{\circ} \mathrm{C}$. The medium was removed and the cells were washed twice with PBS. AO and EB were diluted in PBS and mixed 1:1, and added to the cells. The concentrations of AO and EB were all $20 \mu \mathrm{g} / \mathrm{ml} .{ }^{19)}$ The assess viability, cellular morphology was observed under a fluorescence microscope (LEICA TCS SP2, Germany). Excitation wavelengths and emission wavelengths were $488 \mathrm{~nm}$, $515-545 \mathrm{~nm}$ and $488 \mathrm{~nm}, 575-635 \mathrm{~nm}$. Three separate groups of samples were analyzed, and the number of apoptotic and necrotic cells in five representative fields were counted per experiment. ${ }^{20)}$

Western Blot Analysis PC12 cells were seeded in $75 \mathrm{ml}$ flasks and treated with 3-ODS for $6 \mathrm{~h}$, and $1 \mathrm{mM} \mathrm{MPP}^{+}$for $24 \mathrm{~h}$ at $37^{\circ} \mathrm{C}$. The cells were then harvested and lysed. Protein concentrations were measured using the Bradford assay. ${ }^{21)}$ Samples containing $30 \mu \mathrm{g}$ protein were separated by $12.5 \%$ SDS-polyacrylamide gel electrophoresis (PAGE) ${ }^{22}$ and transferred onto nitrocellulose membranes. After blocking in 5\% non fat dry milk solution in TBST (i.e. washing buffer containing $10 \mathrm{~mm}$ Tris at $\mathrm{pH} 7.5,150 \mathrm{~mm} \mathrm{NaCl}$, and $0.1 \%$ Tween-20) for $1 \mathrm{~h}$ at room temperature, the membranes were incubated overnight at $4{ }^{\circ} \mathrm{C}$ with anti- $\mathrm{TH}$ rat monoclonal antibody $(1: 3000)$, anti-DJ-1 rabbit polyclonal antibody $(1: 2000)$ or anti- $\beta$-actin rabbit polyclonal antibody $(1: 2000)$. Membranes were then incubated with horseradish peroxidase-coupled secondary antibodies, developed with enhanced chemiluminescence detection, and immediately exposed to film. Densitometry results were normalized to $\beta$ actin, and the integrated optical density for each band was quantified using Quantity One software (BIO-RAD, U.S.A.).

Immunofluorescent Analysis PC12 cells were plated on glass coverslips and treated with 3-ODS for $6 \mathrm{~h}$, and then treated with $1 \mathrm{~mm} \mathrm{MPP}{ }^{+}$for $24 \mathrm{~h}$ at $37^{\circ} \mathrm{C}$. The cells were fixed in $4 \%$ paraformaldehyde for $30 \mathrm{~min}$ and permeabilized with $0.3 \%$ Triton X-100 for $5 \mathrm{~min}$. After blocking in $10 \%$ goat serum in PBS for $1 \mathrm{~h}$ at room temperature, cells were incubated overnight at $4{ }^{\circ} \mathrm{C}$ with anti-TH rat monoclonal antibody $(1: 5000)$, then exposed for $1 \mathrm{~h}$ to a fluorescein isothiocyanate (FITC)-coupled goat-anti-mouse antibody at room temperature in the dark. $^{23)}$ Cells were then stained with Hoechst 33342 for $15 \mathrm{~min}$ and, after being sealed by $90 \%$ glycerin, were observed under an epifluorescent microscope (LEICA TCS SP5, Germany). Three separate groups of sam- ples were analyzed, and the optical density of the FITC signal for cells in five representative fields were quantified using Leica confocal software (Germany), per experiment.

Statistical Analysis of the Data The data are expressed as the mean \pm S.D. Statistical comparisons were performed using ANOVA. $p<0.05$ was considered significant

\section{RESULTS}

Effects of 3-ODS on Cell Viability in PC12 Cells Exposed to $\mathrm{MPP}^{+}$, Rotenone or $\mathrm{H}_{2} \mathrm{O}_{2}$ We evaluated the protective effect of 3-ODS on MTT reduction in cultured PC12 cells. Following $24 \mathrm{~h}, 48 \mathrm{~h}$ or $1 \mathrm{~h}$ of $\mathrm{MPP}^{+}$, rotenone or $\mathrm{H}_{2} \mathrm{O}_{2}$ exposure, respectively, at concentrations ranging from 12.5 to $100 \mu \mathrm{g} / \mathrm{ml}$ (Figs. 2A, C), 5 to $50 \mu \mathrm{g} / \mathrm{ml}$ (Fig. 2B), the number of viable cells decreased significantly with $1 \mathrm{mM} \mathrm{MPP}{ }^{+}$, $0.5 \mu \mathrm{M}$ rotenone and $250 \mu \mathrm{M} \mathrm{H}_{2} \mathrm{O}_{2}$ treatment. With all three treatments, the number of viable cells was decreased signifi-
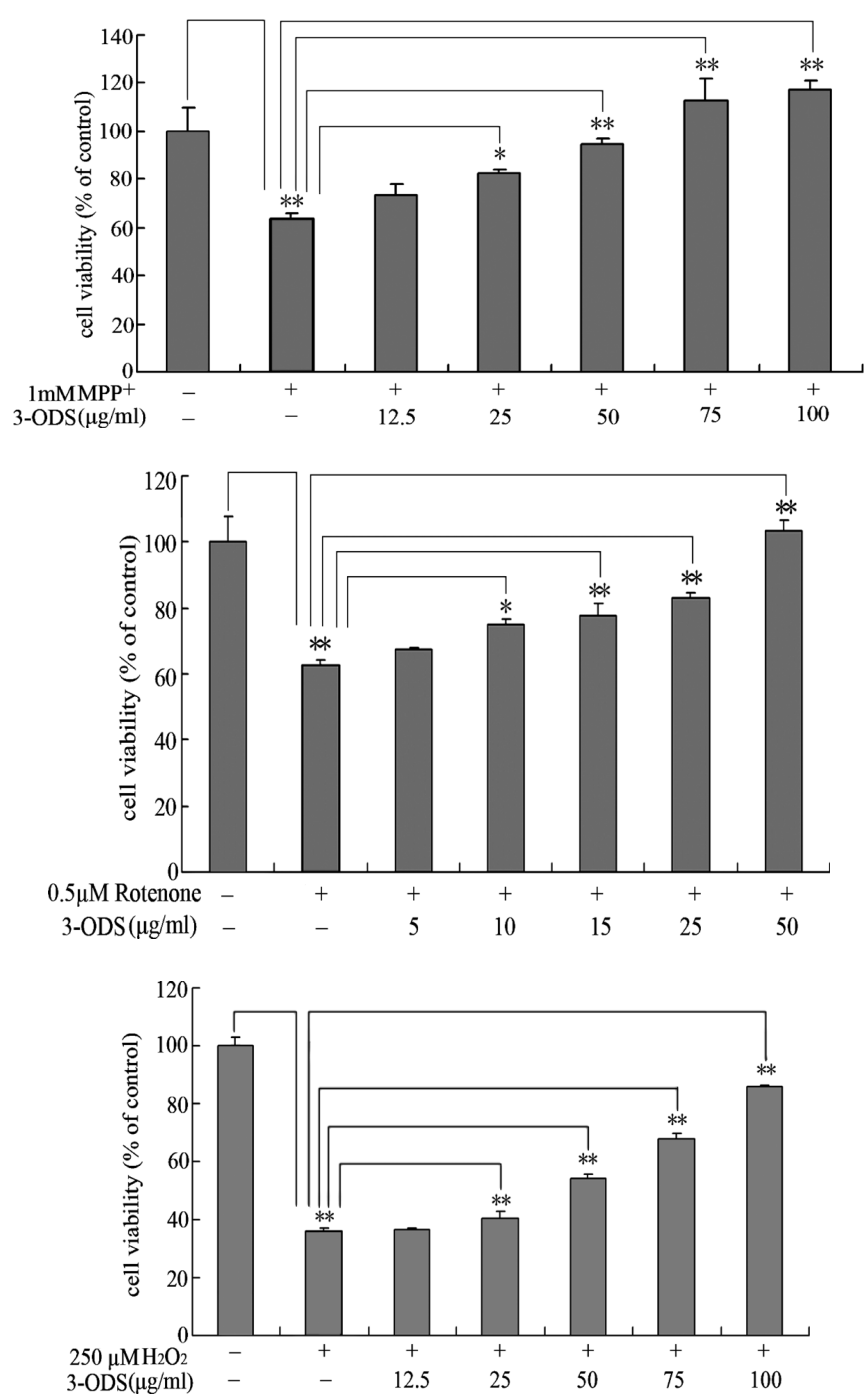

Fig. 2. Pretreatment of 3-ODS Improved Cell Viability after Administration with Various Toxins

(A) Cells were treated with $1 \mathrm{~mm} \mathrm{MPP}+$ for $24 \mathrm{~h}$, with 3-ODS pretreatment for $6 \mathrm{~h}$ (B) Cells were treated with $0.5 \mu \mathrm{M}$ rotenone for $48 \mathrm{~h}$ in the presence of 3-ODS for $6 \mathrm{~h}$. (C) Cells were treated with $250 \mu \mathrm{M} \mathrm{H}_{2} \mathrm{O}_{2}$ for $1 \mathrm{~h}$ in the presence of 3-ODS for $6 \mathrm{~h}$. Data represent the mean \pm S.D. $(n=3)$ from three independent experiments. $* p<0.05$, $* * p<0.01$. 
cantly. However, when samples were pretreated with 3-ODS, the cell viability rates significantly increased in all three conditions in a concentration-dependent fashion.

Effects of 3-ODS Treatment on $\mathrm{MPP}^{+}$-Induced Apoptosis in Cultured PC12 Cells To clarify the protective effects of 3-ODS on $\mathrm{MPP}^{+}$cytotoxicity, we investigated cell morphological changes in the $\mathrm{MPP}^{+}$-treated cells (Fig. 3A). Staining with $\mathrm{AO} / \mathrm{EB}$ demonstrated that control PC12 cells appeared uniformly green. By contrast, orange apoptotic cells or red necrotic cells were evident in PC12 cells treated with $1 \mathrm{~mm} \mathrm{MPP}^{+}$for $24 \mathrm{~h}$. Moreover, orange apoptotic cells were more abundant than red necrotic cells. However, when PC12 cells were treated with $1 \mathrm{mM} \mathrm{MPP}^{+}$in the presence of 3-ODS, the orange apoptotic cells decreased significantly and the green cells increased significantly (Fig. 3B). Figure 3B shows the quantitative analysis of Fig. 3A.

Effects of 3-ODS on TH Protein Expression in MPP $^{+}$. Treated PC12 Cells TH protein expression was measured by Western blot analysis (Fig. 4A) in PC12 cells exposed to $\mathrm{MPP}^{+}$toxicity. The level of $\mathrm{TH}$ protein in the $\mathrm{MPP}^{+}$-treated sample was decreased significantly compared with that of the control (51.67\% of control). Upon pretreatment with 3-ODS, the levels of $\mathrm{TH}$ protein were significantly increased compared to the model (Fig. 4B).

PC12 cells immunoreactive for TH were observed under a fluorescence microscope (Fig. 5A). Bright fluorescence was seen in the cytoplasm of the control PC12 cells. By contrast, fluorescence was weak in $\mathrm{PC} 12$ cells treated with $1 \mathrm{~mm}$ $\mathrm{MPP}^{+}$for $24 \mathrm{~h}$ at $37^{\circ} \mathrm{C}(20.6 \%$ of the control). However, when PC12 cells were treated with $1 \mathrm{mM} \mathrm{MPP}^{+}$in the presence of 3-ODS, strong cytoplasmic fluorescence was observed, similar to that in control cells $(52.3 \%, 61.9 \%, 90.8 \%$ of the control). Figure 5B shows the quantitative analysis of Fig. 5A.

Effects of 3-ODS Treatment on DJ-1 Protein Expression in $\mathrm{MPP}^{+}$-Treated PC12 Cells DJ-1 protein expres-

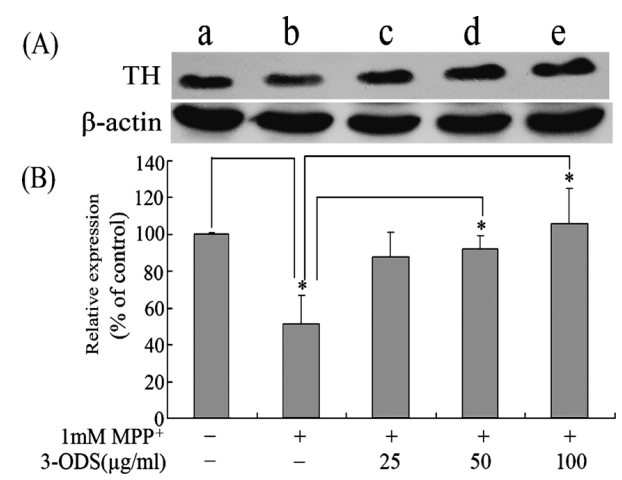

Fig. 4. 3-ODS Increases TH Expression in $\mathrm{MPP}^{+}$-Treated PC12 Cells

(A) Western blot for TH. (a) Control group; (b) $1 \mathrm{mM} \mathrm{MPP}^{+}$; (c) $25 \mu \mathrm{g} / \mathrm{ml} 3$-ODS with $1 \mathrm{~mm} \mathrm{MPP}{ }^{+}$; (d) $50 \mu \mathrm{g} / \mathrm{ml}$ 3-ODS with $1 \mathrm{~mm} \mathrm{MPP}{ }^{+}$; (e) $100 \mu \mathrm{g} / \mathrm{ml} 3$-ODS with $1 \mathrm{~mm} \mathrm{MPP}^{+}$. (B) Quantitative estimation of the bands. Data represent the mean \pm S.D. $(n=3)$ from three independent experiments. Differences in optical density were analyzed by ANOVA. $* p<0.05$.

(A)

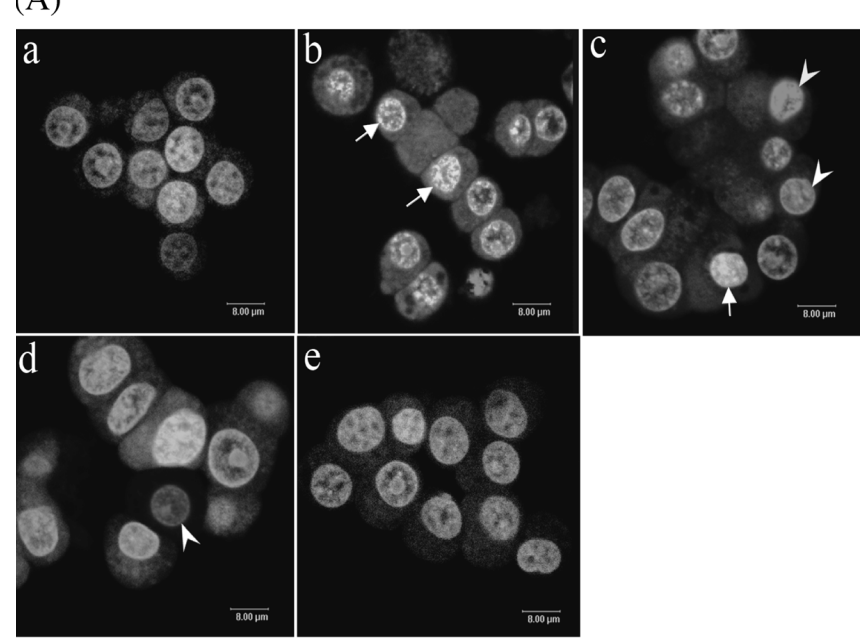

(B)

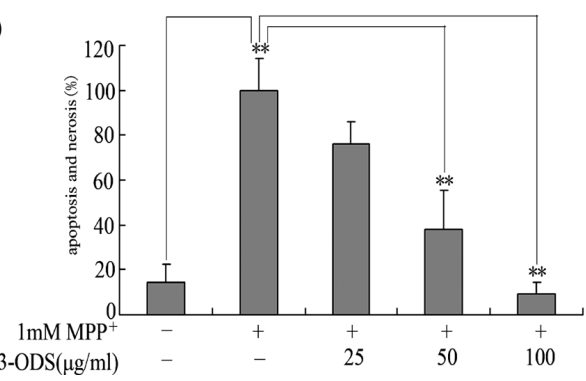

Fig. 3. 3-ODS Reduces $\mathrm{MPP}^{+}$-Induced Apoptosis

$\mathrm{PC} 12$ cells were treated with $1 \mathrm{mM} \mathrm{MPP}^{+}$for $24 \mathrm{~h}$ in the presence of 3 -ODS $(25,50$ or $100 \mu \mathrm{g} / \mathrm{ml})$ for $6 \mathrm{~h}$. The cells were observed by fluorescence microscopy $(40 \times)$ after staining with AO/EB. $\rightarrow$ represents apoptotic cells, < represents necrotic cells. (a) control group; (b) $1 \mathrm{~mm} \mathrm{MPP}{ }^{+}$; (c) $25 \mu \mathrm{g} / \mathrm{ml} 3-\mathrm{ODS}$ with $1 \mathrm{~mm} \mathrm{MPP}{ }^{+}$; (d) $50 \mu \mathrm{g} / \mathrm{ml} 3$ ODS with $1 \mathrm{~mm} \mathrm{MPP}{ }^{+}$; (e) $100 \mu \mathrm{g} / \mathrm{ml} 3-O D S$ with $1 \mathrm{~mm} \mathrm{MPP}^{+}$. The figures are representative of three different experiments.
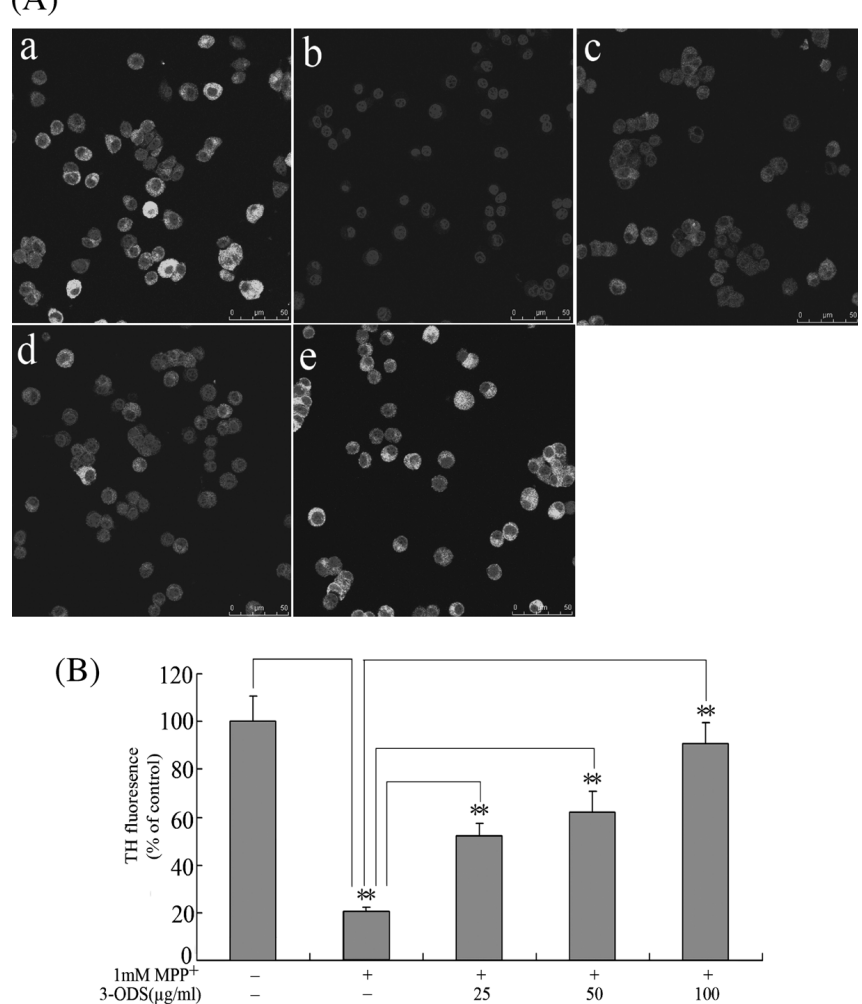

Fig. 5. 3-ODS Increases TH Immunofluorescence in $\mathrm{MPP}^{+}$-Treated PC12 Cells

(A) PC12 cells were observed by fluorescence microscopy $(20 \times)$ after immunostaining. (B) Quantitative evaluation of fluorescence intensity. (a) Control group; (b) $1 \mathrm{~mm}$ $\mathrm{MPP}^{+}$; (c) $25 \mu \mathrm{g} / \mathrm{ml}$ 3-ODS with $1 \mathrm{~mm} \mathrm{M^{+ }}{ }^{+}$; (d) $50 \mu \mathrm{g} / \mathrm{ml}$ 3-ODS with $1 \mathrm{~mm} \mathrm{MPP}{ }^{+}$ (e) $100 \mu \mathrm{g} / \mathrm{ml} 3$-ODS with $1 \mathrm{~mm} \mathrm{MPP}{ }^{+}$. The figures are representative of three different experiments. Data are presented as the mean \pm S.D. from three independent experiments. $* * p<0.01$ 
(A)

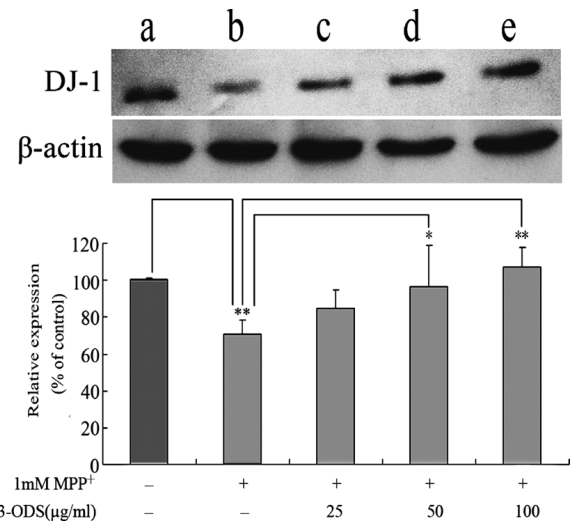

Fig. 6. 3-ODS Treatment Increases DJ-1 Expression in $\mathrm{MPP}^{+}$-Treated PC12 Cells

(A) Western blot for DJ-1. (a) control group; (b) $1 \mathrm{~mm} \mathrm{MPP}{ }^{+}$; (c) $25 \mu \mathrm{g} / \mathrm{ml}$ 3-ODS with $1 \mathrm{mM} \mathrm{MPP}^{+}$; (d) $50 \mu \mathrm{g} / \mathrm{ml} \mathrm{3-ODS} \mathrm{with} 1 \mathrm{~mm} \mathrm{MPP}{ }^{+}$; (e) $100 \mu \mathrm{g} / \mathrm{ml} \mathrm{3-ODS}$ with $1 \mathrm{~mm} \mathrm{MPP}^{+}$. (B) Quantitative estimation of the bands. Data represent the mean \pm S.D. $(n=3)$ from three independent experiments. Differences in optical density were analyzed by ANOVA. $* p<0.05, * * p<0.01$

sion in PC12 cells was measured by Western blot analysis (Fig. 6A). The DJ-1 protein content in the $\mathrm{MPP}^{+}$-treated group was significantly decreased compared to that of the control. In cells pretreated with 3-ODS, the level of DJ-1 protein was significantly greater than that of the model group $(p<0.05, p<0.01)$ (Fig. 6B).

\section{DISCUSSION}

Oxidative damage, mediated by reactive oxygen species (ROS), can affect various biological macromolecules including DNA, lipids, and proteins, thereby impairing cellular function and integrity. This type of damage has been implicated as a major cause of cellular injuries in neurodegenerative disorders. ${ }^{24,25)}$ Among the toxins of interest in the study of neural degeneration, $\mathrm{MPP}^{+}$has been widely used as a dopaminergic neurotoxin because it causes a severe parkinsonian-like syndrome in both animals and humans, caused by a profound loss of dopaminergic cells. ${ }^{26)} \mathrm{MPP}^{+}$also makes the cells more vulnerable to oxidative stress by attenuating cellular antioxidant systems. ${ }^{27)}$ Rotenone, a natural pesticide isolated from plant species belonging to genera Derris and Lonchorcarpus, is a specific inhibitor of mitochondrial complex I. ${ }^{28)}$ Inhibitors of complex I facilitate ROS formation, which produces oxidative stress, leading to the mitochondrial dysfunction that is considered an important cause of neuronal cell death. ${ }^{29,30)}$ Therefore, administration of $\mathrm{MPP}^{+}$and rotenone provide good models for the studies of cellular oxidative stress. $\mathrm{H}_{2} \mathrm{O}_{2}$ is a $\mathrm{ROS}$ that can easily be used as a toxin to establish in vitro models of oxidative stress-induced injury. ${ }^{31)}$ Our current results show that, using these models for oxidative-stress injury, treatment with 3-ODS can significantly ameliorate the negative effects of these toxins in PC12 cells, demonstrating the potential of this xanthone compound to inhibit oxidative cell death.

To further investigate the mechanisms underlying the protective actions of 3-ODS, we measured- $\mathrm{MPP}^{+}$-induced apoptosis in $\mathrm{PC} 12$ cells using a AO/EB staining assay. $\mathrm{MPP}^{+}$ causes oxidative stress damage in PC12 cells, and excessive oxidative injury may induce cell apoptosis or necrosis. Cell apoptosis has been implicated in $\mathrm{MPP}^{+}$toxicity, and several studies have indicated the role of apoptosis in dopaminergic neurons in disease models in vivo ${ }^{32-35)}$ and in vitro. ${ }^{36,37)}$ In the current study, we established that pretreatment of PC12 cells with 3-ODS can prevent $\mathrm{MPP}^{+}$-induced apoptosis.

DJ-1 is a multi-functional protein with roles in anti-oxidative stress function and transcriptional regulation. ${ }^{38)}$ The loss of DJ-1 function has been implicated in both PD and cancer. $^{39)}$ In both cell and animal models, DJ-1 deficiency increases sensitivity to cell death induced by oxidative stress, while the over-expression of DJ-1 has protective effects. ${ }^{40}$ ) Wild type DJ-1 reduces cellular reactive oxygen species and decreases the levels of protein oxidation caused by oxidative stress. $^{41)}$ Furthermore, DJ-1 directly bound to NADH dehydrogenase 1 alpha subcomplex 4 (NDUFA4) and NADH dehydrogenase 1 (ND1), nuclear and mitochondrial DNAencoding subunits of mitochondrial complex I, respectively, and plays a role in maintenance of mitochondrial complex I activity. ${ }^{42)}$ In our study, we find that the expression of DJ-1 in $\mathrm{MPP}^{+}$-treated PC12 cells was significantly decreased. However, the levels of DJ-1 increased markedly after pretreatment with 3-ODS. This suggests that 3-ODS protects PC12 cells partly through the elevation of DJ-1.

$\mathrm{TH}$ is a cytosolic, iron-containing enzyme that catalyzes the rate-limiting step in catecholamine biosynthesis, the ortho-hydroxylation of L-tyrosine to yield L-dopa. ${ }^{43,44)}$ Oxidative damage in the brain can cause an increase in the carbonyl groups present in the enzyme, resulting in the inactivation of $\mathrm{TH}^{45)}$ This $\mathrm{TH}$ inhibition is concurrent with the degeneration of dopaminergic neurons in disease models. TH inactivation, and dopamine synthesis failure, is a neurotoxic process that can serve as a model of $\mathrm{PD} .{ }^{46)}$ In the late phase of $\mathrm{PD}$ animal models induced by $\mathrm{MPP}^{+}, \mathrm{TH}$ activity and $\mathrm{TH}$ protein content are significantly decreased. ${ }^{47)}$ This indicates that $\mathrm{TH}$ is closely related to the genesis and progression of PD. Moreover, DJ-1 stimulates TH activity both by directly binding to $\mathrm{TH}$, and also via the indirect upregulation of $\mathrm{TH}$ gene expression. ${ }^{48)}$ Thus, DJ-1 can indirectly, via $\mathrm{TH}$, increase the dopamine content in brain.

Our results demonstrate that the expression of both DJ-1 and $\mathrm{TH}$ was decreased after $\mathrm{MPP}^{+}$treatment in PC12 cells, but pretreatment with 3-ODS reversed this effect. On one hand, 3-ODS may facilitate the protein expression of DJ-1 and $\mathrm{TH}$, while on the other, 3-ODS may also decrease the degradation of DJ-1 and TH protein. However, the detailed mechanisms of the effects of 3-ODS on the regulation of expression of TH and DJ-1 are not clear, and therefore further studies are needed. The mechanism underlying the protective effects of 3-ODS may involve the many phenol-hydroxyl groups contained in its structure, which have anti-oxidative actions. In addition, as 3-ODS is a xanthone compound, these findings may provide evidence for a role of xanthone compounds in the amelioration of antioxidative stress, thus implicating them as potential therapeutic agents in the treatment of PD.

We have demonstrated that 3-ODS can efficiently protect PC12 cells against $\mathrm{MPP}^{+}$-, rotenone- and $\mathrm{H}_{2} \mathrm{O}_{2}$-induced oxidative injury. In these damage models, 3-ODS increases the viability of PC12 cells, inhibits cellular apoptosis, and elevates the protein expression of $\mathrm{TH}$ and $\mathrm{DJ}-1$. These exciting results include 3 -ODS as an important candidate compound 
for the treatment of PD. Previous reports have found the plant extract phenylethanoid glycoside (cistanche salsa) and other phenolic compounds to have neuroprotective effects in cellular and animal models of $\mathrm{PD}^{49-51)}$; like 3-ODS, these compounds contain many phenol-hydroxyl groups in their structures. The significant antioxidative effects of 3-ODS in the current PD model warrant further study of its anti-PD potential and therapeutic promise.

Acknowledgements We thank Prof. Qi-Hua He, Jian-Ru Yang and Lan Yuan (The Medicine and Health Analysis Center of Peking University) for their help with laser-confocal microscopy analysis. We also thank Prof. De-An Guo (Department of Natural Drugs, School of Pharmaceutical Science, Peking University) for the compounds. We thank Prof. Hiroyoshi Ariga for the anti-DJ-1 rabbit polyclonal antibody. This work was supported by a Grant from the National Natural Science Foundation of China (No. 30973889).

\section{REFERENCES}

1) Thomas B., Beal M. F., Hum. Mol. Genet., 16, R183-R194 (2007).

2) Dorsey E. R., Constantinescu R., Thompson J. P., Biglan K. M., Holloway R. G., Kieburtz K., Marshall F. J., Ravina B. M., Schifitto G., Siderowf A., Tanner C. M., Neurology, 68, 384-386 (2007).

3) Lotharius J., O’Malley K. L., J. Biol. Chem., 275, 38581-38588 (2000).

4) Singer T. P., Ramsay R. R., FEBS Lett., 274, 1-8 (1990).

5) Alam M., Schmidt W. J., Behav. Brain Res., 136, 317-324 (2002).

6) Ghadge G. D., Lee J. P., Bindokas V. P., Jordan J., Ma L., Miller R. J., Roos R. P., J. Neurosci., 17, 8756-8766 (1997).

7) Winklhofer K. F., Haass C., Biochim. Biophys. Acta, 1802, 29-44 (2009).

8) Yacoubian T. A., Standaert D. G., Biochim. Biophys. Acta, 1792, $676-687$ (2009)

9) Satoh T., Sakai N., Enokido Y., Uchiyama Y., Hatanaka H., J. Biochem., 120, 540-546 (1996).

10) Rebois R. V., Reynolds E. E., Toll L., Howard B. D., Biochemistry, 19, $1240-1248$ (1980).

11) Capettini L. S., Campos L. V., Dos Santos M. H., Nagem T. J., Lemos V. S., Cortes S. F., Planta Med., 75, 145-148 (2009).

12) Pedro M., Cerqueira F., Sousa M. E., Nascimento M. S., Pinto M., Bioorg. Med. Chem., 10, 3725-3730 (2002).

13) Bian Q. L. C., Cao L., Xiao P. J., Chin. Pharm.. Sci., 8, 175-176 (1999).

14) Tan P., Hou C. Y., Liu Y. L., Lin L. J., Cordell G. A., Phytochemistry, 31, 4313-4315 (1992).

15) Ming X., Qiu M. H., Nie R. L., Zhang G. L., Chin. Chem. Lett., 11, $709-710(2000)$

16) An L. J., Guan S., Shi G. F., Bao Y. M., Duan Y. L., Jiang B., Food Chem. Toxicol., 44, 436- 443 (2006).

17) Mosmann T., J. Immunol. Methods, 65, 55-63 (1983).

18) Pavlica S., Gebhardt R., Life Sci., 86, 79-86 (2010).

19) Kern J. C., Kehrer J. P., Chem. Biol. Interact., 139, 79—95 (2002).
20) Patsos H. A., Hicks D. J., Dobson R. R. H., Greenhough A., Woodman N., Lane J. D., Williams A. C., Paraskeva C., Gut, 54, 1741-1750 (2005).

21) Bradford M. M., Anal. Biochem., 72, 248-254 (1976).

22) Laemmli U. K., Nature (London), 227, 680 -685 (1970).

23) Nagatsu I., Kondo Y., Inagaki S., Kojima H., Nagatsu T., Histochemistry, 61, 103-109 (1979).

24) Fiers W., Beyaert R., Declercq W., Vandenabeele P., Oncogene, 18, 7719-7730 (1999).

25) Gardner A. M., Xu F. H., Fady C., Jacoby F. J., Duffey D. C., Tu Y., Lichtenstein A., Free Radic. Biol. Med., 22, 73-83 (1997).

26) Hashimoto T., Nishi K., Nagasao J., Tsuji S., Oyanagi K., Brain Res., 1197, 143-151 (2008)

27) Lee H. S., Park C. W., Kim Y. S., Exp. Neurol., 165, 164-171 (2000).

28) Turrens J. F., Boveris A., Biochem. J., 191, 421-427 (1980).

29) Mao Y. R., Jiang L., Duan Y. L., An L. J., Jiang B., Environ. Toxicol. Pharmacol., 23, 314-318 (2007).

30) Wang G., Qi C., Fan G. H., Zhou H. Y., Chen S. D., FEBS Lett., 579 , 4005-4011 (2005)

31) Chai Y., Niu L., Sun X. L., Ding J. H., Hu G., Biochem. Biophys. Res. Commun., 350, 307-314 (2006)

32) Eberhardt O., Schulz J. B., Toxicol. Lett., 139, 135-151 (2003).

33) Tatton N. A., Kish S. J., Neuroscience, 77, 1037-1048 (1997).

34) Turmel H., Hartmann A., Parain K., Douhou A., Srinivasan A., Agid Y., Hirsch E. C., Mov. Disord., 16, 185-189 (2001).

35) Yang L., Matthews R. T., Schulz J. B., Klockgether T., Liao A. W., Martinou J. C., Penney J. B. Jr., Hyman B. T., Beal M. F., J. Neurosci, 18, 8145-8152 (1998)

36) Dodel R. C., Du Y., Bales K. R., Ling Z. D., Carvey P. M., Paul S. M., Neuroscience, 86, 701-707 (1998).

37) Mochizuki H., Nakamura N., Nishi K., Mizuno Y., Neurosci. Lett, 170, 191-194 (1994).

38) Takahashi-Niki K., Niki T., Taira T., Iguchi-Ariga S. M., Ariga H., Biochem. Biophys. Res. Commun., 320, 389-397 (2004).

39) Clements C. M., McNally R. S., Conti B. J., Mak T. W., Ting J. P., Proc. Natl. Acad. Sci. U.S.A., 103, 15091-15096 (2006).

40) Abeliovich A., Flint B. M., J. Neurochem., 99, 1062-1072 (2006).

41) Zhou W., Freed C. R., J. Biol. Chem., 280, 43150-43158 (2005).

42) Hayashi T., Ishimori C., Takahashi-Niki K., Taira T., Kim Y. C., Maita H., Maita C., Ariga H., Iguchi-Ariga S. M., Biochem. Biophys. Res. Commun., 390, 667-672 (2009).

43) Montine T. J., Underhill T. M., Valentine W. M., Graham D. G., Neurodegeneration, 4, 283-290 (1995).

44) Sabban E. L., Semin. Cell Dev. Biol., 8, 101-111 (1997)

45) De La Cruz C. P., Revilla E., Venero J. L., Ayala A., Cano J., Machado A., Free Radic. Biol. Med., 20, 53-61 (1996).

46) Nagatsu T., Neurochem. Res., 15, 425-429 (1990).

47) Rubio-Osornio M., Montes S., Perez-Severiano F., Aguilera P., Floriano-Sanchez E., Monroy-Noyola A., Rios C., Neurochem. Int., 54, $447-451$ (2009)

48) Ishikawa S., Taira T., Niki T., Takahashi-Niki K., Maita C., Maita H., Ariga H., Iguchi-Ariga S. M., J. Biol. Chem., 284, 28832-28844 (2009).

49) Geng X., Tian X., Tu P., Pu X., Eur. J. Pharmacol., 564, 66-74 (2007).

50) Pu X., Song Z., Li Y., Tu P., Li H., Planta Med., 69, 65-66 (2003).

51) Zhang H., Biol. Pharm. Bull., 32, 1866-1869 (2009). 